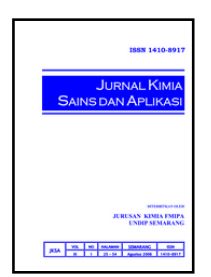

\title{
Uji Aktivitas Antioksidan dengan DPPH fraksi Etil Asetat Daun Bidens pilosa L.
}

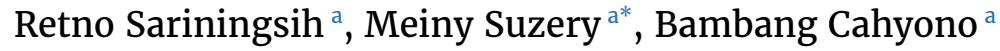 \\ a Organic Chemistry Laboratory, Chemistry Department, Faculty of Sciences and Mathematics, Diponegoro University, Jalan Prof. \\ Soedarto, Tembalang, Semarang \\ * Corresponding author: meiny.suzery@live.undip.ac.id
}

\begin{tabular}{ll} 
Article Info & Abstract \\
\cline { 1 - 3 } $\begin{array}{l}\text { Keywords: } \\
\text { Bidens pilosa, ethyl } \\
\text { acetate fraction, }\end{array}$ & $\begin{array}{l}\text { Research on antioxidant activity test with DPPH fraction of ethyl acetate of Bidens pilosa } \\
\text { leaf. L. has conducted. The objective of this study was to obtain an ethyl acetate fraction } \\
\text { from the methanol fraction of Bidens pilosa L., to obtain data on antioxidant activity, total } \\
\text { phenolate and }\end{array}$ \\
phenolic and flavonoid content of the ethyl acetate fraction. This study was conducted \\
in three stages. The first step was the provision of ethyl acetate fraction by means of \\
stratified extraction of methanol extract. The second stage was antioxidant activity test \\
with DPPH, total phenolate analysis with Folin-Ciocalteu method and total flavonoid \\
analysis. The results showed that ethyl acetate fraction with $0.31 \%$ yield of the initial \\
simplicia weight with brown color having IC 5 value of 62,03 ppm, total content of \\
phenolate equal to 71.717 mg equivalent of galic acid/g extract, total flavonoid content \\
565.108 mg equivalent quercetin/g extract. The ethylacetate fraction of leaf Bidens pilosa \\
L. is antioxidant but needs further research on secondary metabolite compounds that \\
are anti oxidant.
\end{tabular}

Kata Kunci:

Bidens pilosa, fraksi etil asetat, DPPH, total fenolat dan flavonoid

\begin{abstract}
Abstrak
Telah dilakukan penelitian uji aktivitas antioksidan dengan DPPH fraksi etil asetat daun Bidens pilosa L. Tujuan penelitian ini untuk memperoleh fraksi etil asetat dari fraksi metanol Bidens pilosa $\mathrm{L}$, memperoleh data aktivitas antioksidan, kadar total fenolat dan flavonoid dari fraksi etil asetat. Penelitian ini dilakukan dalam tiga tahapan. Tahapan pertama adalah penyediaan fraksi etil asetat dengan cara ekstraksi bertingkat dari ekstrak metanol. Tahapan yang kedua adalah uji aktivitas antioksidan dengan DPPH, analisis total fenolat dengan metode Folin-Ciocalteu dan analisis total flavonoid. Hasil penelitian menunjukkan bahwa fraksi etil asetat dengan rendemen $0,31 \%$ dari berat simplisia awal dengan warna coklat yang mempunyai nilai $\mathrm{IC}_{50} 62,03 \mathrm{ppm}$, kadar total fenolat sebesar 71,717 mg ekuivalen asam galat/g ekstrak, kadar total flavonoid 565,108 mg ekuivalen kuersetin/g ekstrak. Fraksi etilasetat daun Bidens pilosa L bersifat sebagai antioksidan namun perlu dilalukan penelitian lebih lanjut terhadap senyawa metabolit sekunder yang bersifat sebagai anti oksidan.
\end{abstract}

\section{Pendahuluan}

Bidens pilosa merupakan tanaman dari family Asteraceae, yang banyak ditemukan di negara negara tropis dan subtropis. Di daerah Jawa Tengah tumbuhan ini dikenal dengan nama "ketul" atau "ajeran". Kandungan minyak atsiri tanaman Bidens pilosa berpotensi sebagai antioksidan dan juga antibakteri [1].
Sedangkan senyawa flavonoid seperti Centaurein dan Centaureidin dimanfaatkan untuk menstimulasi ekspresi interferon-gama [2], senyawa kuersetin berfungsi sebagai agen antioksidan dan efek hepatoprotektif atau melindungi organ hati [3]. Berdasarkan penelitian yang telah dilakukan sebelumnya, tanaman Bidens pilosa mempunyai senyawa 
metabolit sekunder seperti poliasetilen, flavonoid [4], seskuiterpen, dan diterpen. Senyawa-senyawa tersebut dapat berupa senyawa fenolik maupun non fenolik. Senyawa yang telah dilaporkan tersebut seperti flavonoid dan terpenoid dapat bergungsi sebagai agen antioksidan. Penentuan aktivitas antioksidan pada tanaman Bidens pilosa yang pernah dilakukan adalah menggunakan metode FRAP, radikal hidroksil $(\mathrm{OH})$ dengan metode deoksiribosa, dan metode DPPH [3]. Metode DPPH pada umumya digunakan untuk peredaman radikal bebas dari senyawa-senyawa yang mengandung gugus hidroksil sebagai akibat dari reaksi radikal bebas dari 2,2 difenil-1-pikrilhidrazil dengan senyawa fenolat. Penelitian mengenai Bidens pilosa hingga kini banyak diarahkan pada uji aktivitas, kebanyakan menggunakan ekstrak total atau senyawa murni dari golongan fenolat.

Usaha untuk memperoleh ekstrak yang lebih aktif dibanding dengan crude total, secara teoritis dapat dilakukan melalui proses pemisahan. Pada penelitian ini proses pemisahan dilakukan dengan cara ekstraksi caircair dan dengan kromatografi kolom. Ekstraksi cair-cair dilakukan dengan menggunakan berbagai pelarut dengan kepolaran yang berbeda yaitu n-heksan, diklorometan, dan etil asetat, selanjutnya penelitian ini difokuskan terhadap fraksi etil asetat. Terhadap fraksi etil asetat dilakukan uji penapisan fitokimia, dan beberapa analisis seperti uji aktivitas antioksidan dengan DPPH, analisis total fenolat dan flavonoid.

\section{Metode Penelitian}

Penetuan aktivitas antioksidan menggunakan DPPH

Sebanyak 0,05 g ekstrak metanol dilarutkan kedalam $50 \mathrm{~mL}$ metanol $96 \%$. Hal yang sama dilakukan pula dalam membuat larutan fraksi etil asetat, air dan dibuat dengan berbagai variasi konsentrasi 20, 40, 60, 80, $100 \mathrm{mg} / \mathrm{L}$. Penentuan aktivitas antioksidan dilakukan terhadap berbagai konsentrasi dengan memasukkan 0,2 ml larutan sampel ke dalam vial dan direaksikan dengan $3,8 \mathrm{ml}$ larutan DPPH induk. Campuran dihomogenkan dan didiamkan selama 30 menit di tempat gelap serta ditentukan serapannya menggunakan Spektrofotometer UV-Vis pada panjang gelombang 516,5 nm. Senyawa kuersetin digunakan sebagai pembanding. Kemampuan untuk meredam radikal DPPH (inhibisi) ditentukan dari nilai serapan yang dihasilkan dengan persamaan:

$$
\% \text { Inhibisi }=\frac{\text { A Kontrol }- \text { A sampel }}{\text { A Kontrol }} \times 100 \%
$$

Analisis total Flavonoid. Kurva standar kuersetin dilakukan dengan cara membuat larutan (dalam metanol) dengan konsentrasi 700, 800, 900, 1000, dan $1100 \mathrm{mg} / \mathrm{L}$. Sebanyak 0,5 ml larutan dari berbagai konsentrasi direaksikan dengan $2 \mathrm{ml}$ akuades dan 0,15 ml $\mathrm{NaNO}_{2} 5 \%$ kemudian didiamkan selama 6 menit. Sebanyak 0,15 $\mathrm{ml} \mathrm{AlCl}_{3}$ 10\% ditambahkan ke dalam larutan, kemudian didiamkan kembali 6 menit. Larutan direaksikan dengan $2 \mathrm{ml} \mathrm{NaOH} 4 \%$, kemudian diencerkan hingga volume total mencapai $5 \mathrm{ml}$ dan didiamkan selama 15 menit. Pada akhirnya, absorbansi dari larutan standar diukur pada panjang gelombang 510 nm menggunakan spektrofotometer UV-Vis. Kurva standar diperoleh dari hubungan antara konsentrasi quersetin $(\mathrm{mg} / \mathrm{L})$ dengan absorbansi.

Analisis Total Flavonoid Sampel. Sebanyak 0,3 gram fraksi etil asetat dilarutkan dengan metanol hingga volume $10 \mathrm{ml}$. Sebanyak $0,5 \mathrm{ml}$ larutan ekstrak dicampurkan dengan $2 \mathrm{ml}$ akuades dan 0,15 $\mathrm{ml} \mathrm{NaNO}_{2}$ $5 \%$. Setelah didiamkan selama 6 menit, larutan ditambahkan dengan 0,15 $\mathrm{ml} \mathrm{AlCl}_{3}$ 10\% dan didiamkan kembali 6 menit. Larutan ditambahkan $2 \mathrm{ml} \mathrm{NaOH} \mathrm{4 \%}$ dan diencerkan hingga volume $5 \mathrm{ml}$. Larutan digojok dan didiamkan selama 15 menit. Larutan kemudian diukur serapannya menggunakan spektrofotometer UVVis pada panjang gelombang $510 \mathrm{~nm}$ (dilakukan pengenceran seperlunya agar masuk dalam kurva standar). Kadar flavonoid yang diperoleh merupakan mg ekuivalen quersetin/gram sampel.

Analisis fenolat total. Analisis kuantitatif fenolat total dilakukan sesuai menggunakan metode yang dilakukan oleh Lim dan Quah [5] terhadap fraksi yang menunjukkan tes positif adanya senyawa fenolat. Kurva kalibrasi asam galat dibuat dengan variasi konsentrasi antara 300, 400, 500, 600, $700 \mathrm{mg} / \mathrm{L}$. Masing-masing larutan dipindahkan ke botol vial, kemudian ditambahkan $1 \mathrm{ml}$ reagent Folin-Ciocalteu. Campuran didiamkan selama 5 menit kemudian ditambahkan $3 \mathrm{ml}$ $\mathrm{Na}_{2} \mathrm{CO}_{3} 20 \%$ dan dikocok lalu dibiarkan selama 1 jam pada suhu ruang. Absorbansi seluruh sampel diukur pada panjang gelombang 763,5 nm dengan menggunakan spektrofotometer dan dibuat kurva kalibrasi hubungan antara konsentrasi asam galat (mg/L) dengan absorbansi.

Analisis fenolat total sampel. Sebanyak 0,2 mL dari fraksi etil asetat diencerkan dengan aquades $15,8 \mathrm{~mL}$ dan direaksikan dengan $1 \mathrm{~mL}$ reagen Folin-Ciocalteau selanjutnya dihomogenkan serta didiamkan selama 8 menit. Setelah pengocokan dan pendiaman, sebanyak 3 $\mathrm{mL} \mathrm{Na}_{2} \mathrm{CO}_{3} 20 \%$ ditambahkan ke dalam larutan, dikocok sampai homogen dan didiamkan selama 30 menit pada suhu ruang. Larutan kemudian ditentukan absorbansi pada $\lambda=763,5 \mathrm{~nm}$ menggunakan Spektrofotometer UVVis. Kandungan total fenolat dinyatakan sebagai jumlah mg ekuivalen asam galat/g ekstrak.

\section{Hasil dan Pembahasan}

\section{Hasil Fraksinasi dan Uji Penapisan Fitokimia.}

Hasil fraksinasi menggunakan pelarut etil asetat diperoleh fraksi seberat 8,61 gram berwarna coklat dengan rendemen fraksi $0,31 \%$ dari berat simplisia awal. Hasil fraksinasi ini diperoleh melalui fraksi cair cair dari fraksi metanol dari daun Bidens pilosa $\mathrm{L}(2,7 \mathrm{~kg})$ simplisia kering. 
Tabel 1: Hasil uji penapisan fitokimia fraksi etil asetat beserta crude metanol

\begin{tabular}{ccccc}
\hline $\begin{array}{c}\text { Uji } \\
\text { Fitokimia }\end{array}$ & Reagen & $\begin{array}{c}\text { Fraksi Etil } \\
\text { Asetat }\end{array}$ & $\begin{array}{c}\text { Crude } \\
\text { Metanol }\end{array}$ & Standar \\
\hline Alkaloid & Reagen Meyer & - & + & ++++ \\
& Reagen Dragendorf & - & ++ & \\
Triterpen/ & Reagen Liebermann Burchard & & & ++++ \\
steroid & Triterpen & + & +++ & ++++ \\
& Steroid & - & +++ & ++++ \\
Fenolik & Reagen $\mathrm{FeCl}$ & ++ & +++ & \\
Flavonoid & Serbuk $\mathrm{Mg}+\mathrm{HCl}$ & ++ & +++ & \\
Saponin & Akuades panas $+\mathrm{HCl}$ pekat & - & ++ & ++++ \\
\hline
\end{tabular}

Dari hasil uji skreening fitokimia menunjukkan bahwa fraksi etilasetat mengandung senyawa golongan flavonoid. Namun bila dibandingkan dengan fraksi metanol menunjukkan hasil relatif lebih rendah dibandingkan dengan etilasetat.

\section{Hasil Uji Aktivitas Antioksidan.}

Untuk memntukan aktivitas antioksidan pertama dibuat terlebih dahulu kurva kalibrasi menggunakan kuersetin. Hasil pengukuran kurva kalibrasi kuersetin ditunjukkan pada gambar 1 dan pengukuran hubungan $\%$ inhibisi dan konsentrasi fraksi etil asetat ditunjukkan pada gambar 2 .

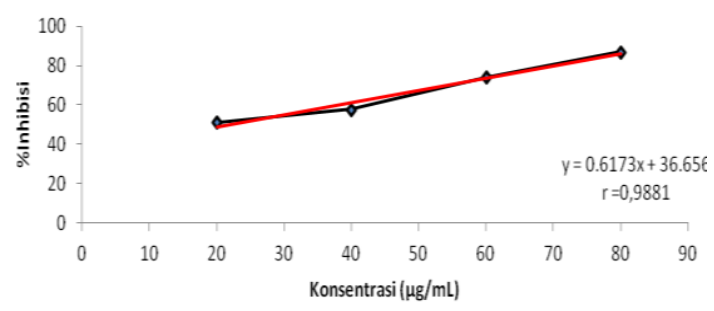

Gambar 1. Grafik hubungan antara \% inhibisi dan konsentrasi larutan standar kuersetin

Berdasarkan uji aktivitas antioksidan dengan DPPH menggunakan standar kuersetin menghasilkan nilai $\mathrm{IC}_{50}$ larutan standar kuersetin sebesar 21,64 ppm yang diperoleh dari perhitungan hasil kurva kalibrasi. Nilai $\mathrm{IC}_{50}$ pada fraksi etil asetat adalah 62,03 ppm yang diperoleh dari perhitungan hasil kurva kalibrasi. Masing-masing sampel uji baik fraksi etil asetat maupun kuersetin mempunyai nilai IC $_{50}$ yang lebih kecil dari $200 \mathrm{mg} / \mathrm{L}$, sehingga dapat diklasifikasikan sebagai senyawa antioksidan yang memiliki aktivitas tinggi [6].

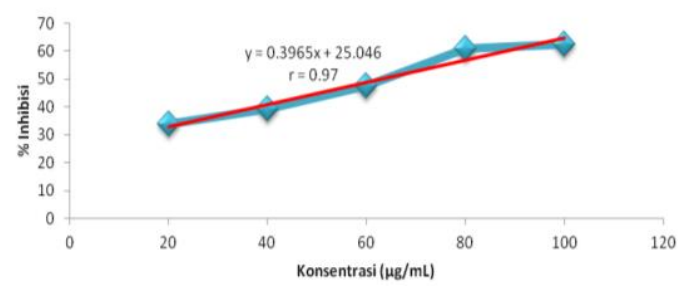

Gambar 2. Grafik hubungan antara \% inhibisi dan konsentrasi fraksi etil asetat

Hasil Analisis Total Flavonoid.

Analisis kuantitatif total flavonoid dilakukan tuntuk mengetahui keberadaan senyawa flavonoid secara kuantitatif pada fraksi etil asetat tanaman Bidens pilosa L. Digunakan kuersetin sebagai senyawa standar, karena senyawa flavonoid dalam tanaman Bidens pilosa L salah satunya adalah kuersetin. Pada analisis ini digunakan persamaan regresi linier dari kurva standar kuersetin yang bernilai $y=0,0003 x+0,007$ dan $r$ bernilai 0,994 . Berdasarkan perhitungan fraksi etil asetat mempunyai kadar flavonoid sebesar 565,108 mg ekuivalen kuersetin/gram ekstrak. Kurva standar kuersetin dapat dilihat pada gambar 3 .

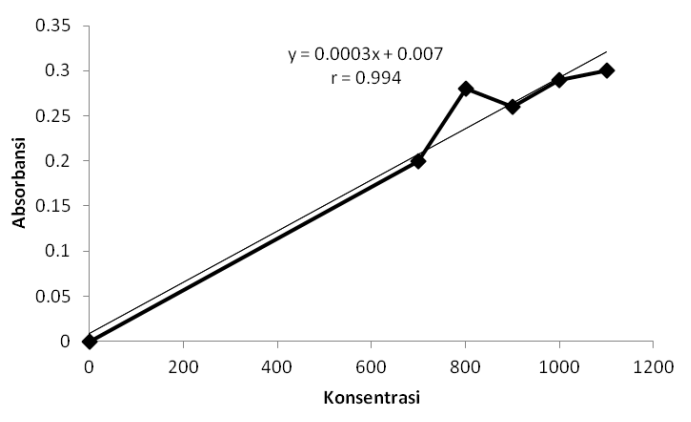

Gambar 3. Kurva kalibrasi kuersetin

Hasil Analisis Total Fenolat.

Analisis kuantitatif total fenolat dilakukan untuk mengetahui keberadaan senyawa fenolat secara kuantitatif pada fraksi etil asetat tanaman Bidens pilosa L. Digunakan standar asam galat karena banyaknya publikasi yang menggunakan senyawa ini sebagai standart sehingga mempermudah memberikan gambaran mengenai kualitas bahan yang dianalisis. Pada analisis ini digunakan persamaan regresi linier dari kurva standar asam galat yang bernilai $\mathrm{y}=0,001 \mathrm{x}+$ 0,027 dengan $r=0,994$. Berdasarkan perhitungan fraksi etil asetat mempunyai kadar fenolat sebesar 71,71 mg ekuivalen asam galat/g ekstrak. Kurva kalibrasi asam galan ditunjukkan pada gambar 3.

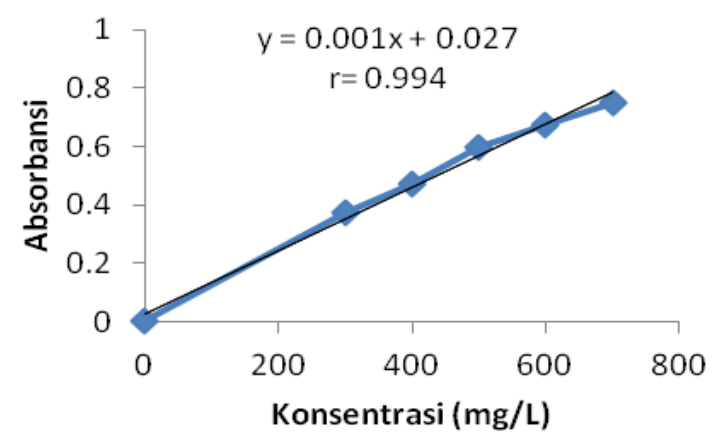

Gambar 3. Kurva kalibrasi asam galat dengan pereaksi Folin-Ciocalteu

Dari data yang sudah dihasilkan diatas meunnjukkan bahwa fraksi etilasetat menunjukkan kadar total fenolat dan flavonoid yang lebih tinggi dari penelitian yang pernah dilakukan oleh Kviecinski $d k k$. [3] yang berasal dari Amerika Utara dan Lee dkk. [7] yang berasal dari Brazil.

\section{Kesimpulan}

Fraksi etil asetat daun Bidens pilosa dari daerah Semarang, Jawa Tengah mengandung flavonoid, fenolat, dan triterpenoid. Fraksi etil asetat berpotensi dikembangkan sebagai senyawa antioksidan. 


\section{Daftar Pustaka}

[1] Fajar Budi Laksono, Enny Fachriyah, Dewi Kusrini, Isolasi dan Uji Antibakteri Senyawa Terpenoid Ekstrak N-Heksana Rimpang Lengkuas Merah (Alpinia purpurata), Jurnal Kimia Sains dan Aplikasi, 17, 2, (2014) 37-42

[2] Raymond Chang, Chemistry, Jhon Wiley \& Sons, Ltd, England, 2005.

[3] Maicon Roberto Kviecinski, Karina Bettega Felipe, João Francisco Gomes Correia, Eduardo Antonio Ferreira, Maria Helena Rossi, Fernando de Moura Gatti, Danilo Wilhelm Filho, Rozangela Curi Pedrosa, Brazilian Bidens pilosa Linné yields fraction containing quercetin-derived flavonoid with free radical scavenger activity and hepatoprotective effects, Libyan Journal of Medicine, 6, 1, (2011) 5651 http://dx.doi.org/10.3402/lim.v6io.5651

[4] Michael R. Hoffmann, Scot T. Martin, Wonyong Choi, Detlef W. Bahnemann, Environmental Applications of Semiconductor Photocatalysis, Chemical Reviews, 95, 1, (1995) 69-96 10.1021/croo033a004

[5] Y. Y. Lim, E. P. L. Quah, Antioxidant properties of different cultivars of Portulaca oleracea, Food Chemistry, 103, 3, (2007) 734-740 http://dx.doi.org/10.1016/j.foodchem.2006.09.025

[6] Marsden S. Blois, Antioxidant Determinations by the Use of a Stable Free Radical, Nature, 181, (1958) 1199 http://dx.doi.org/10.1038/1811199a0

[7] Wen-Chin Lee, Chiung-Chi Peng, Chi-Huang Chang, Shiau-Huei Huang, Charng-Cherng Chyau, Extraction of antioxidant components from Bidens pilosa flowers and their uptake by human intestinal Caco-2 cells, Molecules, 18, 2, (2013) 1582-1601 http://dx.doi.org/10.3390/molecules18021582 